\title{
Soil bacterial communities interact with silicon fraction transformation and promote rice yield after long-term straw return
}

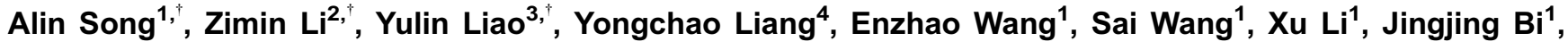 \\ Zhiyuan $\mathrm{Si}^{1}$, Yanhong $\mathrm{Lu}^{3}$, Jun $\mathrm{Nie}^{3, *}$, Fenliang $\mathrm{Fan}^{1, *}$ \\ 1 Key Laboratory of Plant Nutrition and Fertilizer, Ministry of Agriculture and Rural Affairs/Institute of Agricultural Resources and Regional \\ Planning, Chinese Academy of Agricultural Sciences, Beijing 100081, China \\ 2 Earth and Life Institute, Soil Sciences, Université catholique de Louvain (UCLouvain), Croix du Sud 2/L7.05.10, \\ 1348 Louvain-la-Neuve, Belgium \\ 3 Soil and Fertilizer Institute of Hunan province, Hunan Academy of Agricultural Sciences, Changsha 410125, China \\ 4 Ministry of Education Key Laboratory of Environment Remediation and Ecological Health, College of Environmental and Resource Sciences, \\ Zhejiang University, Hangzhou 310058, China
}

H I G H L I G H T S

- Straw returning significantly affects silicon fraction transformation;

- Straw return affects soil microbial community composition;

- Soil microbe interacts with silicon fraction transformation and promote rice yield.

\section{ARTICLE INFO}

Article history:

Received October 23, 2020

Revised December 9, 2020

Accepted December 19, 2020

Keywords:

Bacterial community

Long-term

Silicon fractions

Straw returning

Silicon cycle
GRAPHICAL ABSTRACT

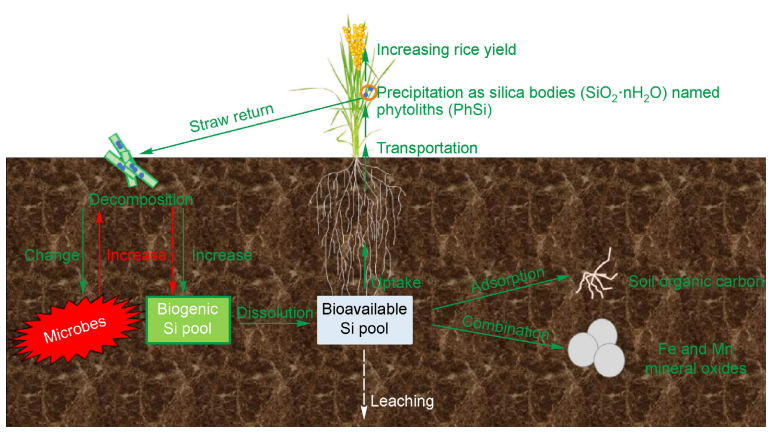

A B S T R A C T

Returning crop straw into the soil is an important practice to balance biogenic and bioavailable silicon (Si) pool in paddy, which is crucial for the healthy growth of rice. However, owing to little knowledge about soil microbial communities responsible for straw degradation, how straw return affects $\mathrm{Si}$ bioavailability, its uptake, and rice yield remains elusive. Herein, we investigate the change of soil Si fractions and microbial community in a 39-year-old paddy field amended by a long-term straw return. Results show that rice straw return significantly increased soil bioavailable $\mathrm{Si}$ and rice yield from $29.9 \%$ to $61.6 \%$ and from $14.5 \%$ to $23.6 \%$, respectively, when compared to NPK fertilization alone. Straw return significantly altered soil microbial community abundance. Acidobacteria was positively and significantly related to amorphous $\mathrm{Si}$, while Rokubacteria at phylum level, Deltaproteobacteria, and Holophagae at class level was negatively and significantly related to organic matter adsorbed and $\mathrm{Fe} / \mathrm{Mn}$-oxide-combined $\mathrm{Si}$ in soils. Redundancy analysis of their correlations further demonstrated that $\mathrm{Si}$ status significantly explained $12 \%$ of soil bacterial community variation. These findings suggest that soil bacteria community and diversity interact with Si mobility by altering its transformation, thus resulting in the balance of various nutrient sources to drive biological Si cycle in agroecosystem.

(c) Higher Education Press 2021

\footnotetext{
* Corresponding authors

E-mail address: niejun197@163.com (J. Nie); fanfenliang@caas.cn (F. Fan)

†These authors contributed equally.
} 


\section{Introduction}

Silicon (Si) is a beneficial element for the healthy growth and development of crops, especially rice (Epstein, 1994; Liang et al., 2015). It significantly increases crop yield by alleviating abiotic (lack of nutrition, heavy metal stress, drought, and salt stress) and biotic (plant diseases and insect pests) stresses (Song et al., 2011; Ning et al., 2014; Liang et al., 2015; Cooke et al., 2016; Coskun et al., 2019). Total Si in the soil is as high as $28.8 \%$, whereas bioavailable Si can be absorbed by plants (Epstein 1994; Liang et al., 2006; Ma et al., 2006; Cornelis et al., 2011; Li and Delvaux, 2019; Vander Linden and Delvaux, 2019). Soil Si has many fractions, including available $\mathrm{Si}$, organic matter adsorbed Si (OM Si), Fe/Mn-oxide-combined $\mathrm{Si}(\mathrm{Fe}-\mathrm{Mn} \mathrm{Si}$, and amorphous Si (ASi), which exhibit a dynamic balance between different $\mathrm{Si}$ fractions that regulate available Si in the soil (Cornelis et al., 2011; Georgiadis et al., 2013; Baráo et al., 2014; Cornelis and Delvaux, 2016; Li et al., 2020; Yang et al., 2020a). Changes in soil available Si are influenced by many management practices, such as slag fertilization, Si fertilization, and returning of straw (Ning et al., 2014; Liang et al., 2015; Samaddar et al., 2019; Li et al., 2020). In recent years, the risk for bioavailable Si deficiency has become obvious with the promotion of high-yield varieties and increase in multiple cropping index (Liang et al., 2015; Marxen et al., 2016; Li and Delvaux 2019).

Being an important renewable organic resource, crop straw contains almost all the required nutrients, including $\mathrm{Si}$. This effect has been highlighted by recent studies (Guntzer et al., 2011; Marxen et al., 2016; Li et al., 2020). It is advantageous than common Si fertilizers (silicate slag and minerals), which are costly and pose potential environmental risks due to heavy metals in the fertilizers (Ning et al., 2014; Liang et al., 2015). Returning crop straw to the soil is an important practice to balance biogenic Si (BSi) and bioavailable Si pool in agricultural soil (Wichramasinghe and Rowell, 2006; Struyf et al., 2010; Guntzer et al., 2011; Vandevenne et al., 2012), resulting in more easily transformed, absorbed, and utilized phytogenic Si (PhSi) (Cornelis and Delvaux 2016; Meunier et al., 2018; Vander Linden and Delvaux, 2019; Li et al., 2020). $\mathrm{PhSi}$ release rate from plant litter is $2-4$ orders of magnitude higher than that of typical primary and secondary silicate minerals at common soil pH (Fraysse et al., 2009). A recent study showed that $51 \%-90 \%$ of $\mathrm{PhSi}$ could be absorbed again by plants through rice straw litter and that $10 \%-49 \%$ could be absorbed into the soil, depending on the dissolution of BSi and soil weathering stages (Li et al., 2020). Therefore, the return of straw substantially improves crop Si and nutrient uptake. In contrast, straw removal may reduce soil available Si pool (Struyf et al., 2010; Keller et al., 2012; Vandevenne et al., 2012), which could explain the decline in yield (Klotzbücher et al., 2015). Thus, these studies indicate that returning straw into soil replenishes bioavailable $\mathrm{Si}$ in the soil, thus increasing crop yield.

Straw return significantly affects soil microbial community composition (Lu et al., 2015; Su et al., 2020). In contrast, straw decomposition is also mainly mediated by soil microorganisms. The amount of soil available $\mathrm{Si}$ could be improved during rice straw decomposition induced by microorganisms (Hossain et al., 2001; Su et al., 2020). In addition, straw return significantly affects the physical, chemical, and biological properties of soil. Numerous studies have focused on the relationship between the effects of straw return and soil organic carbon, soil available $\mathrm{P}$ and $\mathrm{K}$, and other essential nutrients (Phongpan and Mosier, 2003; Guo et al., 2015). However, recent studies have shown that soil bacteria, the dominant kingdom of microorganisms in paddy fields, promote an increase in soil available Si (Karunakaran et al., 2013; Chen et al., 2017). Other researchers also showed that the straw degradation rate was as high as $54.50 \%$ with the increase in generic bacteria that which secrete organic soluble Si minerals (Phutela and Sahni, 2013; Xiong et al., 2014). These results suggest that soil microorganisms play a critical role in regulating soil available $\mathrm{Si}$ by driving straw decomposition. Although the effects of straw return on soil physical and chemical properties have been well studied, the effect of straw return on $\mathrm{Si}$ fractions and soil microbial community composition/microorganisms in paddy fields is yet to be studied.

In this study, a 39-year-old straw counter field was selected to investigate the effect of straw returning on Si fractions distribution, microbial community composition, and rice yield. The results of this study provide an important knowledge basis for beneficial microbial screening in farmland and precise regulation of the effective supply of $\mathrm{Si}$ in soils to maintain and improve crop yield.

\section{Materials and methods}

\subsection{Site description and soil properties}

A long-term experiment site named the Key Field Monitoring Experimental Station for Reddish Paddy Soil Eco-environment in Wangcheng, Ministry of Agriculture of China, was established in 1981. This experimental station is located in Wangcheng County, Hunan Province $\left(112^{\circ} 80^{\prime} \mathrm{E}, 28^{\circ} 37^{\circ} \mathrm{N}\right.$, $100 \mathrm{~m}$ above sea level), which is a typical rice production area in southern China. Between 1981 and 2019, the average annual rainfall and temperature were $1270 \mathrm{~mm}$ and $17^{\circ} \mathrm{C}$, respectively. The soil is a reddish yellow paddy soil derived from quaternary red clay and classified as Fe-accumuliStagnic Anthrosols.

The experiment consists of nine treatments with three replicates in each treatment based on a randomized complete block arrangement. Each plot with a size of $66.7 \mathrm{~m}^{2}$ is separated by a cement band $(30 \mathrm{~cm}$ in width) and blocks are separated by two $50 \mathrm{~cm}$ width cement ditches used for irrigation and drainage. Four treatments with three repetitions were selected in this study: (1) nitrogen $(\mathrm{N})$ and phosphorus (P) were added by urea and calcium superphosphate, respectively, and referred to as NP; (2) rice straw (S) was 
applied on the basis of NP treatment and referred to as NPS; (3) N, P, and potassium (K) fertilizers were added by urea, calcium superphosphate, and potassium chloride, respectively, and referred to as NPK; and (4) rice S was applied on the basis of NPK treatment and referred to as NPKS. The Nfertilizer rate was $150 \mathrm{~kg} \mathrm{~N} \mathrm{ha}^{-1}$ (early rice) and $180 \mathrm{~kg} \mathrm{~N} \mathrm{ha}^{-1}$ (late rice). In addition, $50 \%$ of $\mathrm{N}$ was applied as a base fertilizer before transplanting and $50 \%$ of $\mathrm{N}$ was applied as a top dressing at the tillering stage. The $\mathrm{P}$ - and $\mathrm{K}$-fertilizer rates were $38.7 \mathrm{~kg} \mathrm{P} \mathrm{ha}^{-1}$ and $99.6 \mathrm{~kg} \mathrm{~K} \mathrm{ha}^{-1}$, respectively. In each rice season, all of these fertilizers were applied as a baseline fertilizer before transplanting. Rice straw of $2.625 \mathrm{t} \mathrm{ha}^{-1}$ (dry weight) in each season was applied by cutting the straw into pieces of $10-20 \mathrm{~cm}$ length before soil plowing. The rice cultivars were conventional varieties in early rice and a hybrid variety (Oryza sativa L. cv. Xiang 67) in late rice. Other management issues for all treatments were consistent with typical local field management by farmers during the rice cropping season.

\subsection{Sample collection}

Soils were collected from the top layer $(0-20 \mathrm{~cm})$ of five randomly selected positions within each plot before commencement of the experiment in 2019. Soils were thoroughly pooled together as a composite sample from each plot and transported to the laboratory immediately. Twenty grams of soil was stored at $-80^{\circ} \mathrm{C}$ for further molecular analysis, whereas $500 \mathrm{~g}$ of soil was dried for physical and chemical analysis.

\subsection{Physical-chemical analysis of soils}

Both soil exchangeable ammonium $\left(\mathrm{NH}_{4}{ }^{+}\right)$and nitrate $\left(\mathrm{NO}_{3}{ }^{-}\right)$ were extracted with $0.01 \mathrm{M} \mathrm{CaCl}_{2}$ and analyzed calorimetrically using a Lachat flow-injection autoanalyzer (Lachat Instrument, Mequon, WI, USA). The Olsen-P concentrations (Ava. $\mathrm{P}$ ) in soils were extracted by $0.5 \mathrm{M}$ sodium bicarbonate and then measured by ascorbic acid method (Watanabe and Olsen, 1965). Soil available $P$ was extracted with $1 \mathrm{M}$ ammonium acetate and determined using a flame photometer (FP6400A, Aopu, Shanghai, China). Soil pH was measured in a ratio of $1: 5$ soil to $\mathrm{H}_{2} \mathrm{O}$ slurry mixture. Soil organic carbon (OC) was measured by high temperature (oil bath) $\mathrm{K}_{2} \mathrm{Cr}_{2} \mathrm{O}_{7}$ oxidation (Bu et al., 2020).

\subsection{Determination of different Si forms in soils}

We applied sequential Si extraction to soil samples to assess the effects of long-term rice residue return on various Si pools in the paddy soils. This extraction method followed the procedure developed by previous studies (Tessier et al., 1979; Kurtz et al., 2002; Georgiadis et al., 2013; Yang et al., 2020a). Using this stepwise extraction process, different $\mathrm{Si}$ fractions were extracted and determined as follows:

Soil available Si (step 1): Na-acetate Si extraction (Si $\mathrm{NaOAc-HOA}$ ) generally presents available and soluble $\mathrm{Si}$ that are directly exchangeable with soil solution (Sauer et al. 2006; Liang et al., 2015). Thus, Na-acetate extraction (NaOAc-HOA) was broadly adopted in literature for analyzing the potential of Si source addition on available Si in soils (Liang et al., 2015; Song et al., 2017). This system was used to ensure a better assessment of the comparison between our experimental results and those published in literature. This study also used $0.01 \mathrm{~mol} \mathrm{~L}^{-1} \mathrm{NaOAc-HOA}(\mathrm{pH} 4.0)$ buffer to extract soil available Si (Ava Si).

Si adsorbed in organic matter (step 2): Some labile Si could be adsorbed in soil organic matter/residues (e.g., humic compounds). With their decomposition, some Si adsorbed by organic matter release mobile $\mathrm{Si}$, leading to an increase in plant-available/bioavailable Si pool (Cornelis et al., 2011; Georgiadis et al., 2013). In this study, we used $\mathrm{H}_{2} \mathrm{O}_{2}$ to decompose soil organic matter in order to extract soil OM Si. The soil sample was first treated with a $30 \% \mathrm{H}_{2} \mathrm{O}_{2}$ solution at room temperature. Then, $5 \mathrm{~mL}$ of $30 \% \mathrm{H}_{2} \mathrm{O}_{2}$ was added to the residue from step 1 . The sample was heated to $85^{\circ} \mathrm{C} \pm 2^{\circ} \mathrm{C}$ for $1 \mathrm{~h}$ twice and dried. Then, $30 \mathrm{~mL} 1 \mathrm{~mol} \mathrm{~L}^{-1}$ acid Na-acetate buffer solution at $\mathrm{pH} 4.0$ was added. The mixture was shaken for $16 \mathrm{~h}$ and centrifuged. Then, the supernatant was tested for OM Si concentrations.

Si combined with Fe/Mn-oxide (step 3): Labile Si can be chemisorbed in pedogenic oxides and hydroxides (Fe and Mn hydroxides; Fe-Mn Si). The change in physical-chemical properties ( $\mathrm{pH}$ or redox conditions) during paddy rice cultivation results in dissolution and reprecipitation of pedogenic Fe-Mn hydroxides (Saller et al., 2006; Cornelis et al., 2011; Li and Delvaux, 2019), which partly releases mobile and

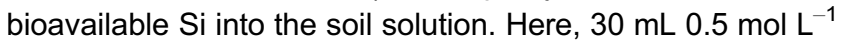
$\mathrm{NH}_{2} \mathrm{OH} \cdot \mathrm{HCl}$ solution was added to the residue from step 2. The mixture was shaken for $16 \mathrm{~h}$ and centrifuged. This step dissolves pedogenic oxides and hydroxides ( $\mathrm{Fe}$ and $\mathrm{Mn}$ hydroxides) to extract soil Fe/Mn-oxide Si (Fe-Mn Si). The supernatant was tested for Fe-Mn Si concentrations.

Amorphous Si (ASi). The remaining soil samples after step 3 were used to extract amorphous Si (ASi) using a $30 \mathrm{~mL} 0.5$ mol $\mathrm{L}^{-1} \mathrm{NaOH}$ solution. The samples were placed in an ultrasonic water bath for $1 \mathrm{~h}$, shaken for $16 \mathrm{~h}$, and centrifuged. The supernatant was tested for ASi concentrations (Georgiadis et al., 2013). Silicon in all extracts from all steps was determined by molybdenum blue colorimetry at $650 \mathrm{~nm}$ (Song et al., 2016; Song et al., 2017).

\subsection{Determination of Si concentrations in straw}

The plant straw samples (excluding leaves and sheath) were selected to analyze Si concentration by molybdenum blue colorimetry at $650 \mathrm{~nm}$.

\subsection{Measurement of rice yield}

Rice yield in triplicate was calculated using rice grain in selected $66.7 \mathrm{~m}^{2}$ area of each plot after harvest. The collected rice grain was dried and weighed during the early rice harvest season. 


\subsection{DNA extraction and microbial community analysis}

DNA of the soil and roots was extracted with Fast DNA SPIN Kit for Soil and FastPrep-24 machine (No.8080878, Irvine, California, USA) according to the manufacturer's instructions. Successful DNA extraction was confirmed by agarose gel electrophoresis and quantified with Nanodrop2000 spectrophotometer (Thermo Fisher Scientific). The extracts were then stored at $-20^{\circ} \mathrm{C}$ until microbial community analysis.

DNA samples for the microbial community analysis were diluted to $2 \mathrm{ng} \mu \mathrm{L}^{-1}$. The common bacterial primer pair $515 \mathrm{~F}-$ $806 R$ was selected for polymerase chain reaction (PCR) amplification due to its high coverage of bacteria and archaea and low affinity with plastid 16S rRNA genes (Pereira and Castro, 2014; Wang et al., 2020). A unique 12-bp tag was attached to the 5'-end of each primer for each DNA sample. The $25-\mu \mathrm{L}$ PCR mixtures contained $2 \mu \mathrm{L}$ template DNA, $2 \mu \mathrm{L}$ dNTPs, $0.5 \mu \mathrm{L}$ forward and reverse primers, $0.25 \mu \mathrm{L}$ rTaq (Takara), $2.5 \mu \mathrm{L} 10 \times$ rTaq buffers, and $16.75 \mu \mathrm{L}$ molecular biology-grade water. All reactions were performed in triplicate using a Bio-Rad PCR machine (PTC 200, Bio-Rad, Hercules, CA, USA) at a cycler setting of initial $94^{\circ} \mathrm{C}$ denaturation for 4 min, followed by 25 cycles of denaturing at $94^{\circ} \mathrm{C}$ for $1 \mathrm{~min}$, $55^{\circ} \mathrm{C}$ annealing for $1 \mathrm{~min}$, and $72^{\circ} \mathrm{C}$ extension for $2 \mathrm{~min}$, with a final extension at $72^{\circ} \mathrm{C}$ for $10 \mathrm{~min}$. Equal moles of amplicons were pooled and gel-purified using a PCR amplicon purification kit (Tiangen Technologies, Beijing, China). The library was constructed with an Ion Plus Fragment Library Kit and lon PGM Template OT2 $400 \mathrm{Kit}$ and subsequently sequenced with lon PGM Sequencing 400 Kit and Ion 318TM Chip Kit v2 on lon Torrent PGM machine (Life Technologies, Carlsbad, CA, USA).

Sequences with a quality score greater than 20 and without mismatches in the barcode and primer were processed further. The sequences were trimmed to $200 \mathrm{bp}$ before clustering with UPARSE at a $97 \%$ similarity level (Edgar, 2013). Chimeras in the sequences were filtered with UCHIME (Edgar et al., 2011). Sequence analysis was performed with USEARCH package (Edgar, 2010). Representative sequences were classified by RDP pipeline (Wang et al., 2007). The operational taxonomic unit (OTU) table was refined to 8993 sequences per sample for 16S. The sequences were deposited in the Genome Sequence Archive in the BIG Data Center of Chinese Academy of Sciences (accession code: CRA003169), which is publicly accessible in http://bigd.big.ac.cn/gsa.
Bacterial abundances were calculated by multiplying the relative abundances of the phylum and class. Differences between the abundance of phyla in the different treatments were compared using an in-house custom R script (Robinson et al., 2010).

\subsection{Statistical analysis}

One-way analysis of variance (Lugtenberg and Kamilova, 2009) was employed to test for the significance of the treatment effects on concentrations of different $\mathrm{Si}$ forms, $\mathrm{NH}_{4}{ }^{+}, \mathrm{NO}_{3}{ }^{-}$, organic matter, $\mathrm{pH}$, and abundances of bacteria. Microsoft Excel 2013 (Microsoft Corporation, Seattle, WA, USA) and SAS Windows version 9.1 (SAS Institute Inc., Cary, NC, USA) were used for the statistical analysis. Principal coordinates analysis (PCoA) ordination, based on BrayCurtis distances of the relative abundances of phyla detected in each sample, was performed with the "vegan" package (Oksanen et al., 2007) in R statistical environment (Team, 2014). The correlation between species and environmental factors was calculated according to the given species and environmental factors (Spearman correlation). When the absolute value of retained Spearman was greater than 0.6 and $p$ was less than 0.05 , the given species were cut off at top the relative abundance of 35 and each network analysis was based on six examples including 3 sub-samples (replicates). gePHI was used to show the results (Barberán et al., 2012; Zhao et al., 2019). All statistical analysis was done in $R$ environment. All figures were illustrated using Sigma Plot software (Systat Software Inc., version 12.5).

\section{Results}

\subsection{Physicochemical properties}

Compared with non-straw amendment, straw return significantly increased soil $\mathrm{pH}$ and available $\mathrm{P}$ under NP or NPK treatments and significantly increased total $\mathrm{N}$ and available $\mathrm{K}$ only under NPK treatment. Organic matter (OM) concentrations showed increasing trend, but no significant difference between straw returning and no straw returning under NP or $\mathrm{NPK}$ treatments. However, both $\mathrm{NH}^{4}-\mathrm{N}$ and $\mathrm{NO}^{3}-\mathrm{N}$ significantly decreased after straw return in any of the treatment type relative to control (Table 1 ).

Table 1 Soil physicochemical properties under NP, NPK treatments with or without straw returning

\begin{tabular}{cccccccc}
\hline Treatments & $\mathrm{pH}$ & $\begin{array}{c}\text { Total } \mathrm{N} \\
\left(\mathrm{g} \mathrm{kg}^{-1}\right)\end{array}$ & $\begin{array}{c}\mathrm{NH}^{4}-\mathrm{N} \\
\left(\mathrm{mg} \mathrm{kg}^{-1}\right)\end{array}$ & $\begin{array}{c}\mathrm{NO}^{3}-\mathrm{N} \\
\left(\mathrm{mg} \mathrm{kg}^{-1}\right)\end{array}$ & $\begin{array}{c}\text { Ava. P } \\
\left(\mathrm{mg} \mathrm{kg}^{-1}\right)\end{array}$ & $\begin{array}{c}\text { Ava. K } \\
\left(\mathrm{mg} \mathrm{kg}^{-1}\right)\end{array}$ \\
\hline NP & $5.71 \pm 0.06 \mathrm{~b}$ & $3.15 \pm 0.09 \mathrm{~b}$ & $4.37 \pm 0.12 \mathrm{a}$ & $1.31 \pm 0.04 \mathrm{a}$ & $42.66 \pm 3.17 \mathrm{~b}$ & $37.49 \pm 2.40 \mathrm{c}$ & $35.07 \pm 0.28 \mathrm{~b}$ \\
$\left(\mathrm{~g} \mathrm{~kg}^{-1}\right)$
\end{tabular}




\subsection{Soil Si pool, straw Si, and rice yield}

Rice straw return significantly enhanced Si concentrations when compared to those in NP or NPK treatment alone (Fig. 1A). The soil available Si significantly $(P<0.01)$ increased $25.35-32.75 \mathrm{mg} \mathrm{kg}^{-1}$ and $26.14-42.23 \mathrm{mg} \mathrm{kg}^{-1}$ with rice straw when compared to no straw returning under NP and NPK treatments, respectively. Compared to no straw returning under NP, we found that $\mathrm{OM} \mathrm{Si}, \mathrm{Fe}-\mathrm{Mn} \mathrm{Si}$, and $\mathrm{ASi}$ concentrations in NP + straw significantly $(P<0.01)$ increased $72.70-90.89 \mathrm{mg} \mathrm{kg}^{-1}, 103.32-108.87 \mathrm{mg} \mathrm{kg}^{-1}$, and 8450.64 $11713.07 \mathrm{mg} \mathrm{kg}^{-1}$, respectively. Similarly, OM Si, Fe-Mn Si, and ASi concentrations in NPK + straw increased 77.62 $117.24 \mathrm{mg} \mathrm{kg}^{-1}, 101.50-111.33 \mathrm{mg} \mathrm{kg}^{-1}$, and 10327.07 $14650.63 \mathrm{mg} \mathrm{kg}^{-1}$ in NPK + straw when compared to no straw returning under NPK.

Silicon concentration in straw (not including leaves) significantly $(P<0.01)$ increased $34.05-45.41 \mathrm{~g} \mathrm{~kg}^{-1}$ and $33.59-42.09 \mathrm{~g} \mathrm{~kg}^{-1}$ with rice straw when compared to no straw returning under NP and NPK treatments, respectively (Fig. 1B). The rice yield was also increased by straw return 5418 $6199 \mathrm{~kg} \mathrm{ha}^{-1}$ and 6699-7099 kg ha ${ }^{-1}$, respectively (Fig. 1C).

\subsection{Soil bacterial communities}

Soil bacterial communities mainly contain microbial diversity and community. Three alpha diversity indices (Coverage, Chao, and Shannon) were used to evaluate the soil bacterial community (Table 2). The high coverage estimator (coverage index>0.99) indicated that bacterial OTUs were well-captured in the samples. The Shannon diversity index varied from 10.16 to 10.40 , whereas no significant $(P>0.05)$ difference in coverage was noted among all treatments. Straw return in NPKS showed significant $(P<0.01)$ low index values in both Shannon and Chao than other treatments.

A total of 783736 high-quality 16S rRNA gene reads were obtained for all 12 samples and clustered into 12204 OTUs. The OTU composition and structure differed significantly $(P<0.01)$ among all treatments (Fig. 2). Specifically, Venn diagram revealed 4233 common OTUs among the four groups and 54838-00NP, NPS, NPK, and NPKS soils had 785, 724, 632, and 635 unique OTUs, respectively (Fig. 2A). PCoA clustered soil bacteria by four treatments (Fig. 2B).

Major phyla and classes were identified. Proteobacteria (34.95\%-42.20\%), Acidobacteria (12.91\%-13.91\%), and
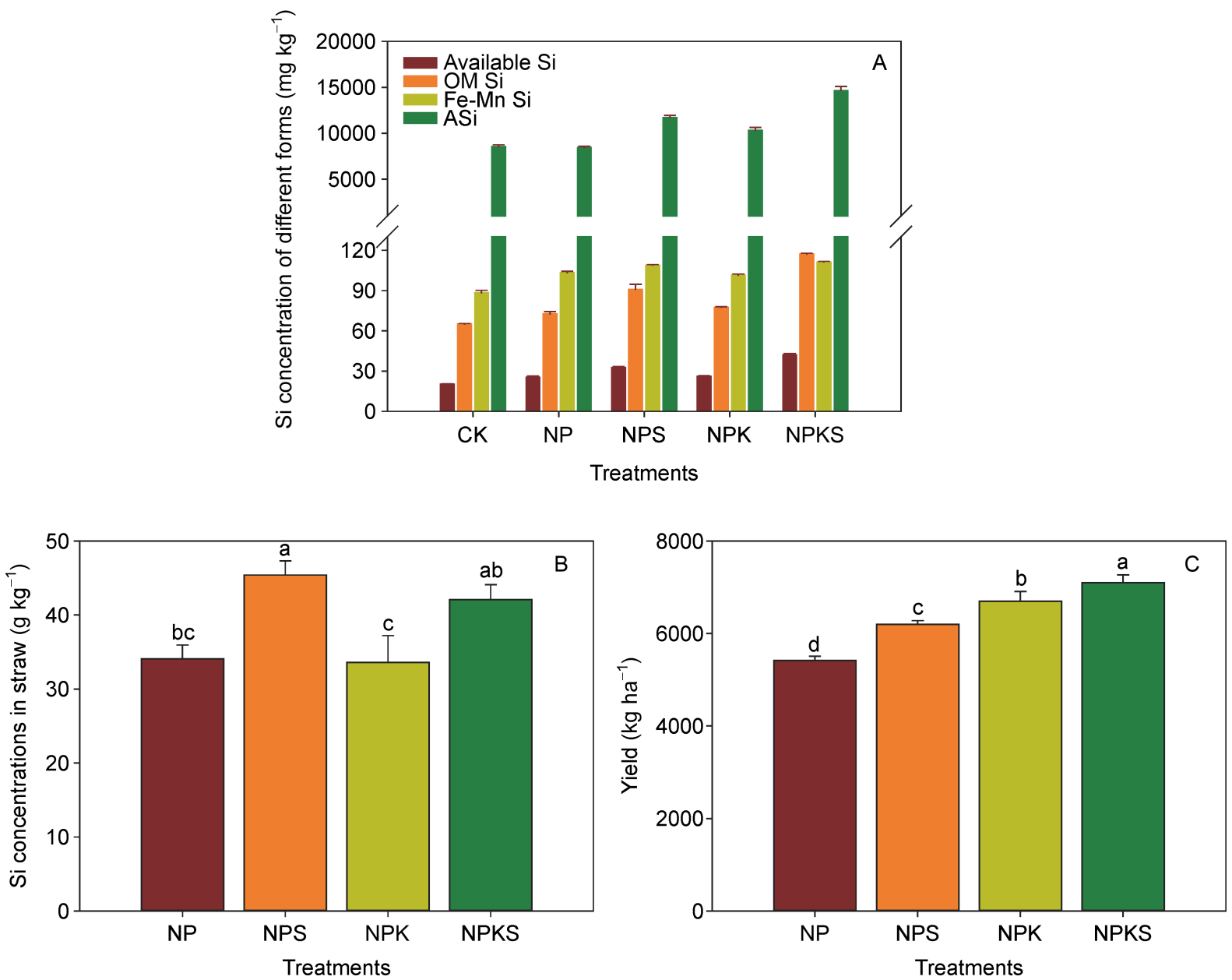

Fig. 1 Si concentrations of different forms in soil (A), straw (B), and yield under NP or NPK treatments with or without straw returning. Different letters indicate significant difference at 0.05 probability level of the same indicators under different treatments based on Duncan test. Vertical bars represent standard errors $(n=3)$. 
Table 2 Mean alpha diversity indexes of the microbial communities under NP, NPK treatments with or without straw returning $(n=3)$

\begin{tabular}{cccc}
\hline & Coverage & Chao & Shannon \\
\hline NP & $0.99 \pm 0.00 \mathrm{a}$ & $4629.44 \pm 26.64 \mathrm{a}$ & $10.40 \pm 0.02 \mathrm{a}$ \\
NPS & $0.99 \pm 0.00 \mathrm{a}$ & $4468.57 \pm 91.66 \mathrm{ab}$ & $10.28 \pm 0.11 \mathrm{ab}$ \\
NPK & $0.99 \pm 0.00 \mathrm{a}$ & $4352.44 \pm 35.07 \mathrm{~b}$ & $10.30 \pm 0.02 \mathrm{ab}$ \\
NPKS & $0.99 \pm 0.00 \mathrm{a}$ & $4426.50 \pm 54.82 \mathrm{~b}$ & $10.16 \pm 0.03 \mathrm{~b}$ \\
\hline
\end{tabular}

Note: results are expressed as the mean \pm standard error $(n=3)$; Different small letters indicate significant differences between treatments for that parameter. Coverage index, evaluating microbial community coverage. Chao index, evaluating microbial community richness. Shannon index, evaluating microbial community diversity.

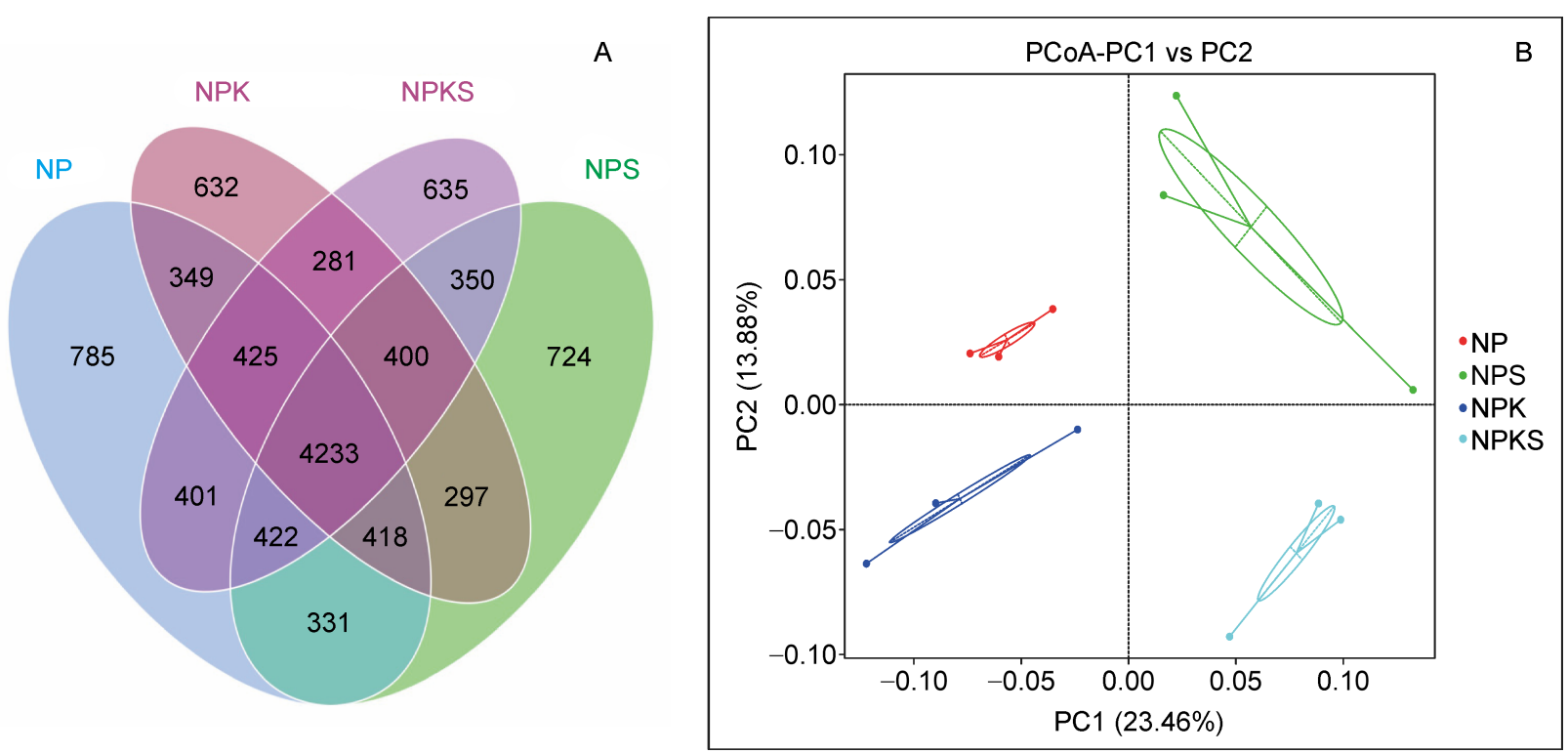

Fig. 2 Venn diagram (A) and Principal coordinates analysis-PCoA (B) in microbial community compositions among NP and NPK treatments with or without straw returning.

Chloroflexi $(8.25 \%-12.67 \%)$ were the three most abundant phyla in all treatments (Fig. 3). Straw return in both NPS and NPKS significantly decreased the relative abundance of Proteobacteria when compared to other treatments (Fig. 3A), while it significantly increased the relative abundance of Chloroflexi under treatment with NPS when compared to NP (Fig. 3A). The relative abundance of Proteobacteria and Chloroflexi at phylum level responded differently to straw return under NP and NPK (Fig. 3B, C).

\subsection{Correlations between Si pool and bacterial community}

The concentrations of different Si fractions (Ava Si, Fe-Mn Si, $\mathrm{OM} \mathrm{Si}$, and $\mathrm{ASi}$ ), in addition to soil $\mathrm{pH}, \mathrm{NH}^{4}-\mathrm{N}, \mathrm{NO}^{3}-\mathrm{N}, \mathrm{Ava}$. $\mathrm{P}$, Ava. $\mathrm{K}$, total $\mathrm{N}$, and $\mathrm{OC}$, were significantly correlated with the bacterial community structure (Redundancy analysis, Fig. 4A). When dividing those environmental variables into two groups of different Si forms (Ava. Si, Fe-Mn Si, OM Si, and ASi) and chemical factors $\left(\mathrm{pH}, \mathrm{NH}_{4}-\mathrm{N}, \mathrm{NO}_{3}-\mathrm{N}\right.$, Ava. P, Ava. K, total $\mathrm{N}$, and $\mathrm{OC}$ ), the concentrations of different Si forms explained $11.83 \%$ of the community variations, while chemical factors explained $29.05 \%$ of the community variations (VPA analysis, Fig. 4B). However, the interactive effect of the two groups was much more substantial, explaining $59.12 \%$ of the total variations.

At phylum level, OM. $\mathrm{Si}, \mathrm{ASi}, \mathrm{pH}$, total $\mathrm{N}$, and $\mathrm{OC}$ were negatively related to the abundance of Rokubacteria; $\mathrm{NH}_{4}{ }^{+}-\mathrm{N}$ and $\mathrm{NO}_{3}{ }^{-} \mathrm{N}$ negatively affected the relative abundance of Chloroflexi; and $\mathrm{NO}_{3}{ }^{-} \mathrm{N}$ positively affected the relative abundance of Proteobacteria (Fig. 5A). At the class level, different Si fractions and chemical factors, except for $\mathrm{NH}_{4}{ }^{+}-\mathrm{N}$ and Ava. K, were negatively correlated with Holophagae abundances. OM. Si, Fe-Mn. Si, ASi, and total $\mathrm{N}$ were negatively correlated to the abundance of Deltaproteobacteria. $\mathrm{NH}_{4}{ }^{+}-\mathrm{N}$ and $\mathrm{NO}_{3}{ }^{-}-\mathrm{N}$ were positively correlated with the abundance of Deltaproteobacteria. Anaerolineae and Bacteroidia abundance were only correlated with chemical factors (Fig. 5B). 

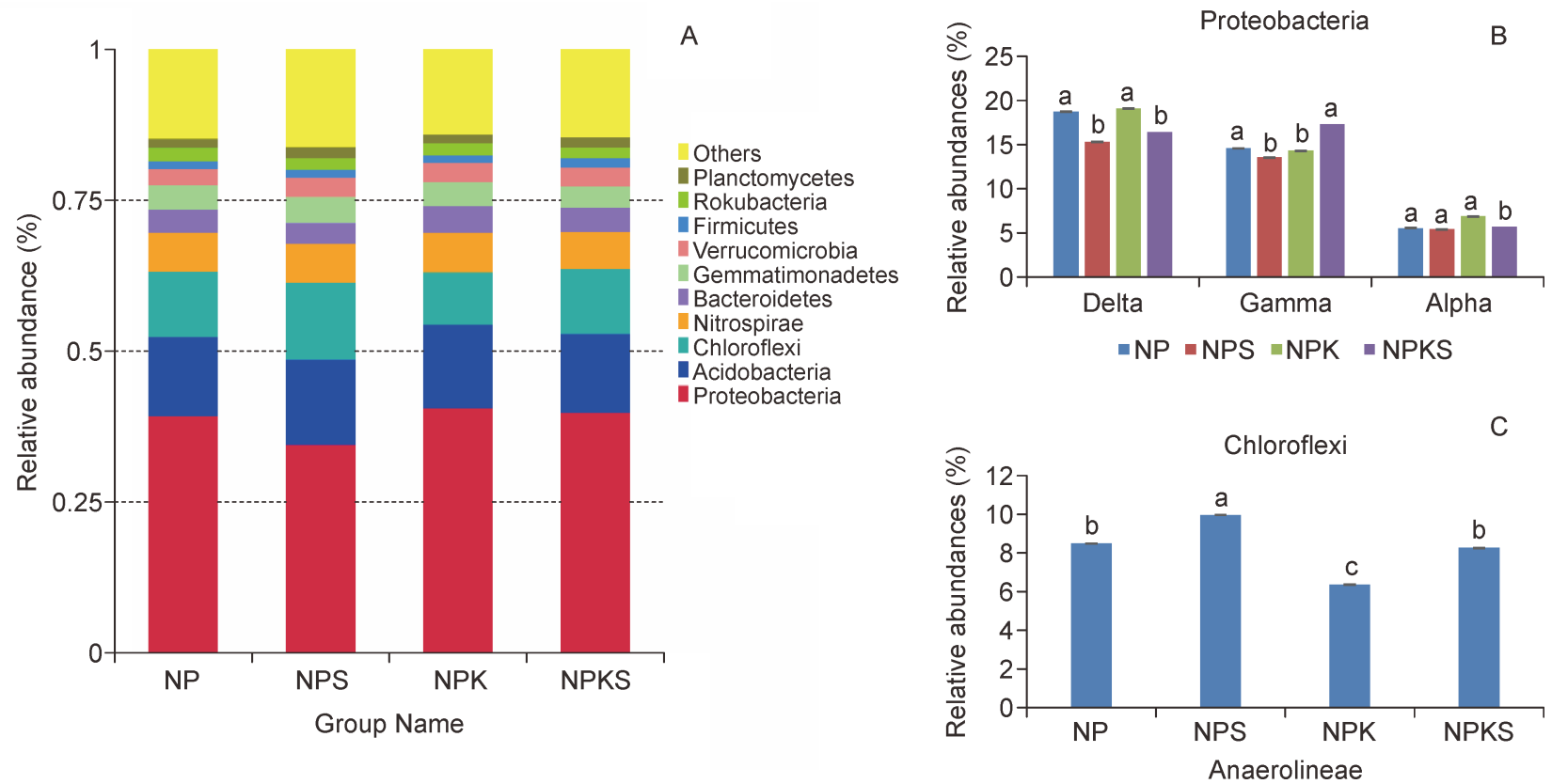

Fig. 3 Relative abundance of bacteria microbial phyla under NP and NPK treatments with or without straw returning.

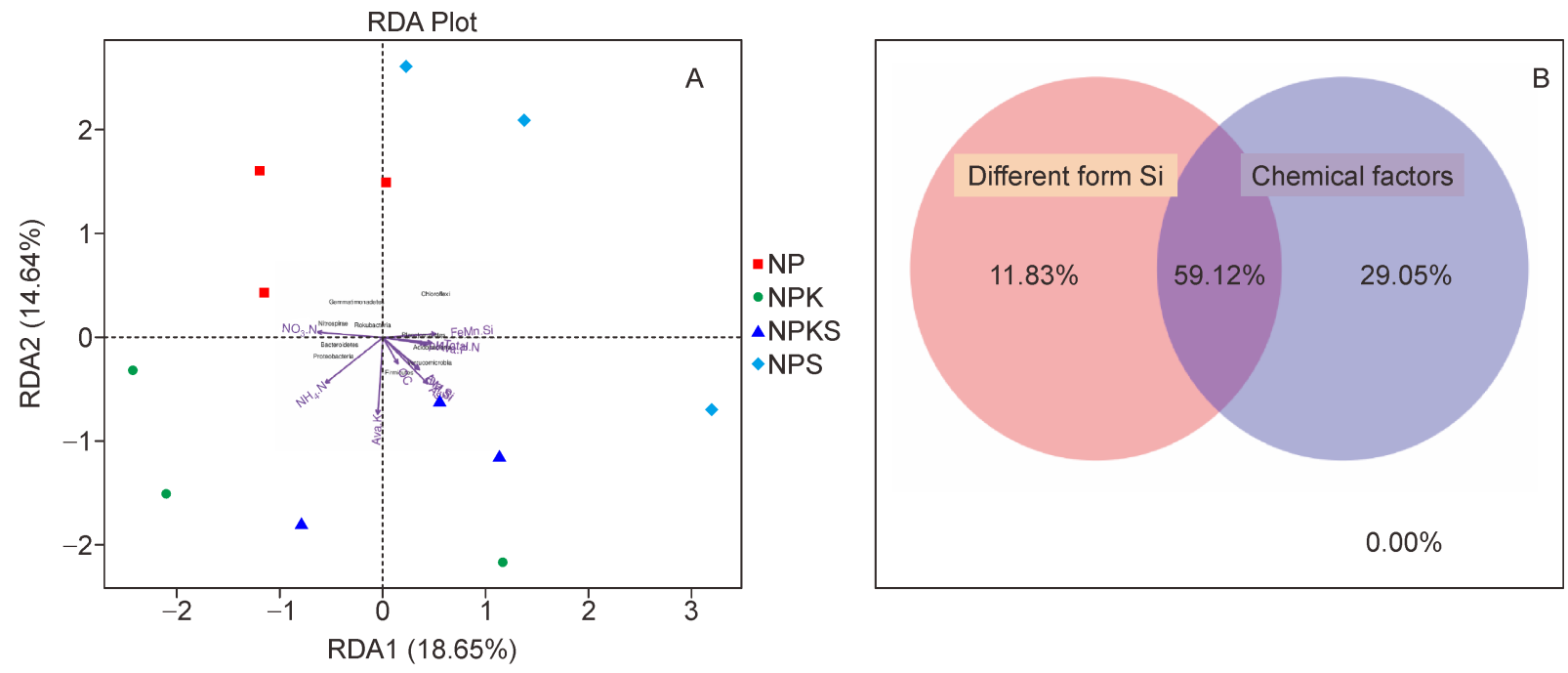

Fig. 4 Redundancy analysis (RDA) of the correlations between bacterial phylum and environment variables (A) and Variance Partitioning Analysis (VPA) (B) under NP and NPK treatments with or without straw returning. For VPA, variables presented in CCA were divided into two groups: Different forms of $\mathrm{Si}$ (including Ava Si, OM Si, Fe-Mn Si, and ASi) and Chemical factors (including $\mathrm{pH}, \mathrm{NH}_{4} . \mathrm{N}, \mathrm{NO}_{3} . \mathrm{N}$, Ava.P, Ava.K, Total $\mathrm{N}$, and $\mathrm{OC}$ ).

We constructed a co-occurring network to verify the correlation among all Si fractions, chemical factors, yield, and bacterial at a genus level in soils. We found that the node of yield was much larger than other nodes of Si fractions, chemical factors, and bacterial at genus level, presenting a much stronger correlation between yield and bacterial nodes under the control condition (Fig. 6A). In contrast, the nodes of different $\mathrm{Si}$ fraction were much larger than other taxa under the condition of straw return, presenting a much stronger correlations between Si fraction and bacterial nodes (Fig. 6B).

\section{Discussion}

4.1 The effect of straw return on soil available $\mathrm{Si}$, rice $\mathrm{Si}$ uptake, and yield

Both rice straw return under NP and NPK treatments improved soil available $\mathrm{Si}$ concentrations and crop Si uptake (Fig. 1). This finding corresponds to previous results of other studies (Marxen et al., 2015; Li et al., 2020). Thus, recycling rice straw contributes to Si nutrient management. The 
A

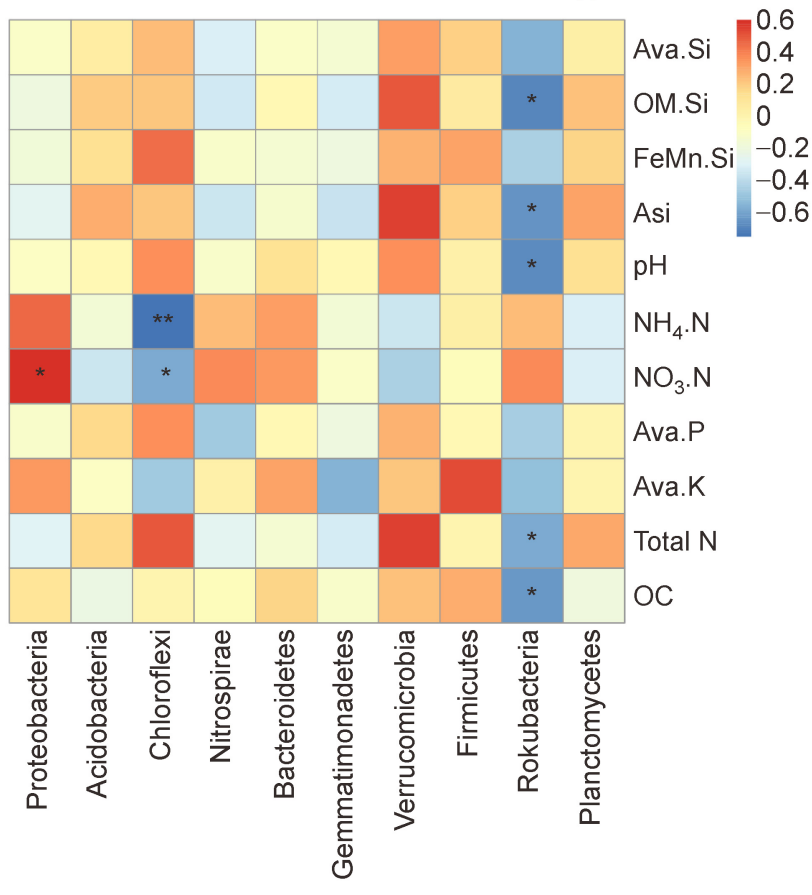

B

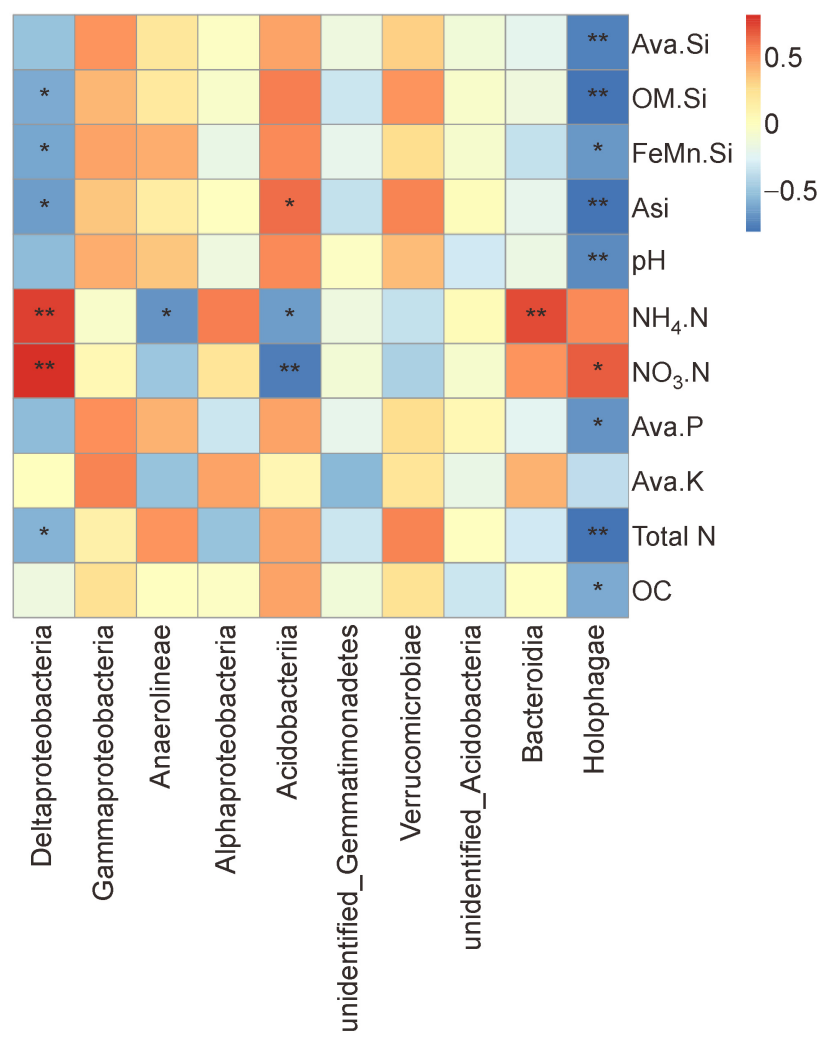

Fig. 5 Spearman correlation analysis between soil environmental variables and relative abundance of bacterial communities at the phylum (A) and class (B) levels. Only the top 10 abundant phyla and class are shown in this figure. Vertical is environmental factor information, while horizontal is species information. The corresponding value of the intermediate heat map is Spearman correlation coefficient $R$, which is between -1 and 1 . $R>0$ means positive correlations, $R<0$ means negative correlations and * denotes significance at $P<0.05,{ }^{* *}$ denotes significance at $P<0.01$.

retention of straw in the field is important for recycling $\mathrm{Si}$ and enhancing rice yield (Carey et al., 2015; Klotzbücher et al., 2015; Liang et al., 2015; Fig. 6), since a large proportion of the aboveground phytogenic $\mathrm{Si}(\mathrm{PhSi})$ uptake (approximately $80 \%)$ is retained in the straw rather than in the harvested grain (Carey et al., 2015; Li and Delvaux, 2019). For instance, Dobermann and Fairhurst (2000) estimated that $40-70 \mathrm{~kg}$ $\mathrm{ha}^{-1} \mathrm{Si}$ was held in $1 \mathrm{Mg}$ of rice straw. Moreover, $\mathrm{Li}$ and Delvaux (Li and Delvaux, 2019) estimated that the global crop takes up 213.8 Tg Si/year, whereas rice straw contributes to $39.0 \%$ of these $\mathrm{PhSi}$ amounts. Once returned to soils, they increased the soil biogenic Si pool (Fig. 1A), balancing the bioavailable Si pool in the soil solution (Marxen et al., 2015; Li et al., 2020). In contrast, this finding provides novel evidence that crop harvest decreased the pool of bioavailable Si and BSi (Struyf et al., 2010; Vandevenne et al., 2012; Carey et al., 2015; Li and Delvaux, 2019). Many farmers have exported Si from paddy fields by removing straw residues with harvest, limiting crop growth due to nutrient loss (N, P, and $\mathrm{K}$ ), especially $\mathrm{Si}$, which corresponds to our experimental results. After continuous removal of straw for 39 years, the concentrations of total $\mathrm{N}, \mathrm{P}, \mathrm{K}, \mathrm{SOC}$, and $\mathrm{pH}$ significantly decreased in both NP and NPK without straw return (Table 1); particularly, the bioavailable $\mathrm{Si}$ concentration significantly decreased up to $66.59 \%$. The loss of rice yield was largely reduced by $31.02 \%$. These findings positively highlight that removing rice straw diminishes the nutrients of $\mathrm{N}, \mathrm{P}, \mathrm{K}$, especially $\mathrm{Si}$, and $\mathrm{SOC}$ in paddy fields, largely affecting soil health and plant growth. In contrast, its return is one possible alternative important management tool for recycling $\mathrm{Si}$ (Fig. 1B) and other nutrients, thereby enhancing rice yield (Fig. 1C).

This study also observed that straw return significantly increased $\mathrm{OM} \mathrm{Si}, \mathrm{Fe}-\mathrm{Mn} \mathrm{Si}$, and $\mathrm{ASi}$, all of which are major sources of mobile $\mathrm{Si}$ that drive the mobility of available $\mathrm{Si}$ in soils (Cornelis and Delvaux, 2016; Li et al., 2020; Yang et al., 2020a). There is thus a dynamic balance of mutual transformation between components, regulating soil bioavailable Si pool. This study observed that after straw return, soil ASi significantly increased up to $41.87 \%$ over 39 years. Considering that straw return offers a direct source of phytoliths in this study, we believe that this increase in the ASi pool can be attributed to the increase in soil BSi pool after the straw return. These BSi fractions are highly soluble, thus releasing soil available Si (Fraysse et al., 2009; Li et al., 2020). Supplying phytolith-rich straw can increase the pool of bioavailable Si by improving the pool of BSi (Keller et al., 


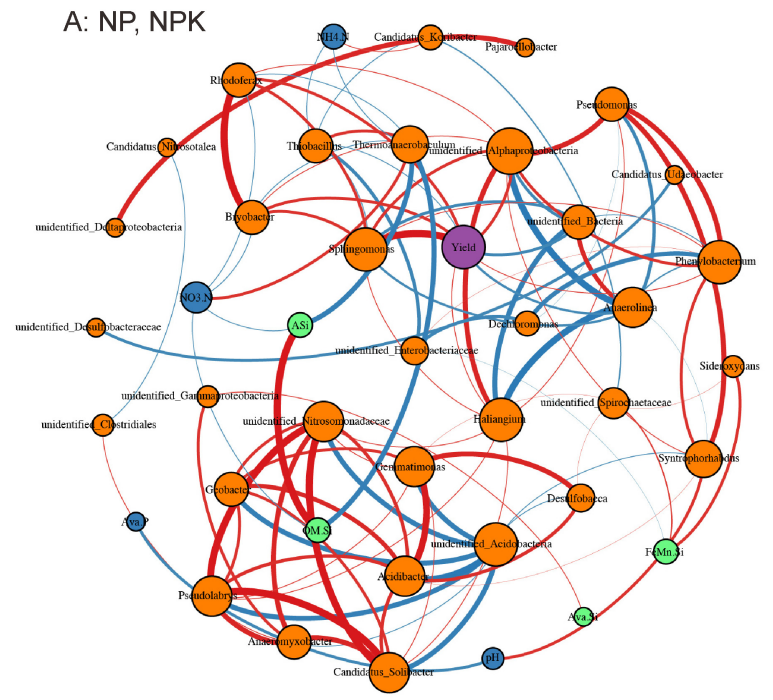

genus

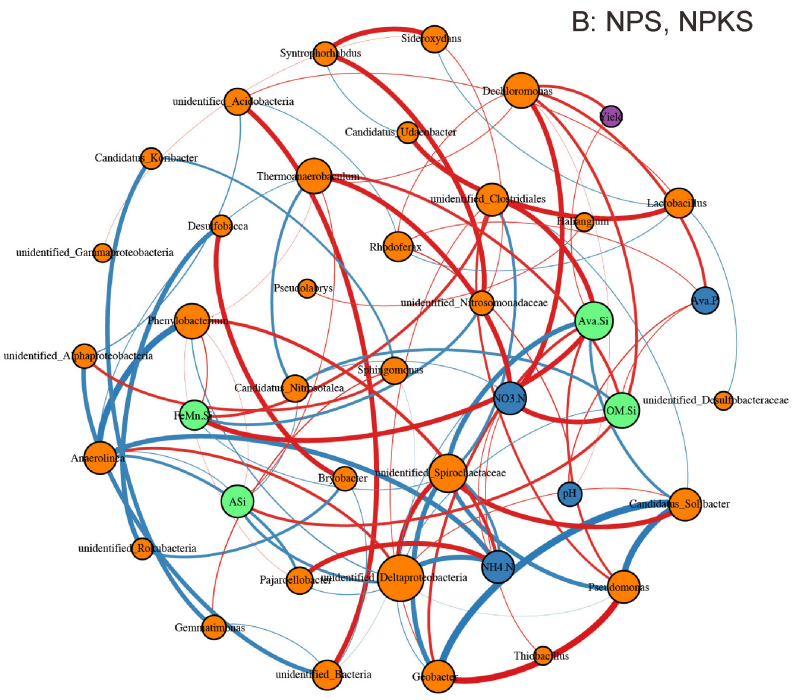

Chemical factors Yields

Fig. 6 The networks visualize the effects of fertilization treatment (including NP, NPK, NPS, NPKS) on co-occurrence pattern between Si fractions, chemical factors, yield, and bacterial at the genus level in soils. The networks were constructed based on correlation analysis. A connection stands for a strong (Spearman's $P>0.6)$ and significant $(P<0.05)$ correlation. The size of each node is proportional to the number of connections (that is, degree). Here, nodes filled in orange are bacterial taxa; green refers to different Si fractions taxa, blue refers to chemical factors taxa, and purple refers to yield taxa. Positive correlations are colored red, while negative correlations are colored blue.

2012; Marxen et al., 2016; Li et al., 2020; Yang et al., 2020b), which depends on soil pH buffering capacity (Li et al., 2019). Our results highlighted that long-term straw return significantly increased the soil $\mathrm{pH}$ from 5.7 to 6.2 , providing a potential solution for widespread soil acidification problem in agricultural soils. The increased $\mathrm{pH}$ partly promotes the dissolution of $\mathrm{BSi}$, releasing $\mathrm{Si}$ into the soil solution, potentially representing a key mechanism to increase the pool of bioavailable $\mathrm{Si}$ in soils after the straw return. Thus, long-term straw return should be considered a potential fertilizer by increasing the BSi pool (Guntzer et al., 2011; Yang et al., 2020a; Li et al., 2020), supplying bioavailable $\mathrm{Si}$ in soil solution for a long time to increase crop yield. However, the increased bioavailable $\mathrm{Si}$ can be impacted by $\mathrm{OM}$ and pedogenic minerals ( $\mathrm{Fe}, \mathrm{Al}$, and $\mathrm{Mn}$ oxides) via their adsorption (Cornelis et al., 2011; Georgiadis et al., 2013; Meunier et al., 2018; Li et al., 2020). Significant increases in the soil $\mathrm{OM} \mathrm{Si}$ and $\mathrm{Fe}-\mathrm{Mn} \mathrm{Si}$ concentration with straw return under NP and NPK treatments may arise from the presence of increased bioavailable $\mathrm{Si}$ adsorbed by organic matter and combined by pedogenic $\mathrm{Fe}$ and $\mathrm{Mn}$ oxides during paddy rice cultivation. In addition, the release of large amounts of nutrients and water-soluble $\mathrm{OM}$ during straw decomposition subsequently enhanced microbial growth and soil processes (Yan et al., 2019), indirectly controlling Si mobility (see more discussion in Section 4.3).
4.2 The effect of straw return on soil microbial community composition

Soil bacterial community plays a key role in regulating soil processes and its composition determines agricultural soil sustainability (Rêgo et al., 2018). The straw return provides energy and nutrients for soil bacterial growth (Chen et al., 2017) and many studies have shown that straw return redistributes the soil bacterial community composition (Lu et al., 2015; Zhao et al., 2017; Su et al., 2020). Based on three alpha diversity indices, the coverage, richness, and diversity of the soil bacterial community were well-captured in the studied soils with different treatments (Table 2; Fig. 2). Therefore, our experimental findings indicate that straw return significantly altered microbial community abundance, whereas microbial community diversity did not significantly differ under NP and NPK treatments (Table 2; Fig. 3). This finding is consistent with previous research showing that rice straw return does not influence bacterial community diversity, but significantly affects its community abundance (Wu et al., 2011). This effect could be attributed to two impact factors, as described below.

First, straw return significantly increased soil $\mathrm{OC}$ and $\mathrm{N}$ (Table 1) to provide direct energy source and nutrients to soil bacteria, increasing their growth and abundance. This study 
also observed that, under both straw treatments, soil microbial abundance (Firmicutes, Verrucomicrobia, Gammaproteobacteria, and others, especially Chloroflexii and Gammaproteobacteria) increased relative to control (Fig. 3). A previous study documented that Proteobacteria are composed of many classes sensitive to copiotrophic conditions (Esperschütz et al., 2007). For instance, this study also observed that the abundance of Gramma-Proteobacteria was significantly improved after OM incorporation (straw return), due to the increase in soil $\mathrm{OC}$ and $\mathrm{N}$ (Table 1; Fig. 3), which positively corresponds to the findings of a previous study (Bei et al., 2018). Second, due to the loss of some key energy and nutrients resulting from plant growth, bacterial community diversity decreased. This study highlights that the sources of nutrient/energy $\left(\mathrm{NH}_{4}{ }^{+}-\mathrm{N}\right.$ and $\left.\mathrm{NO}_{3}{ }^{-}-\mathrm{N}\right)$ in both straw treatments for long-term intensive rice cultivation significantly decreased (Table 1); thus, the soil bacterial community diversity was weakened (Fig. 3). For instance, this study observed that straw addition under NP and NPK treatments significantly decreased Proteobacteria. This effect mainly resulted from a decrease in Deltaproteobacteria (Fig. 3). This finding was similar to that of Li et al. (2014), which demonstrated that Proteobacteria was less abundant in healthy soils than in wiltdiseased bacterial soil.

Most interestingly, chemical indices of $\mathrm{pH}, \mathrm{NH}_{4}{ }^{+}-\mathrm{N}, \mathrm{NO}_{3}{ }^{-} \mathrm{N}$, available $\mathrm{P}$ and $\mathrm{K}$, total $\mathrm{N}$, and $\mathrm{OC}$ explained $29.05 \%$ of the soil microbial community (Fig. 4), highlighting their importance for bacterial communities (Fig. 6). Accordingly, the sources of energy and nutrients, including $\mathrm{OM}$, total $\mathrm{N}, \mathrm{NH}_{4}-\mathrm{N}$, and $\mathrm{NO}_{3}-$ $\mathrm{N}$, were significantly related to Rokubacteria, Chlorflexi, and Proteobacteria at the phylum level (Fig. 5A) and Holophagae, Bacteroidia, Acidobacteria, and Deltaproteobacteria at the class level (Fig. 5B). In particular, our experimental results also indicate that straw return resulted in a higher abundance of Chloroflexi compared to control, due to increase in Anaerolineae (Fig. 3). Chloroflexi is generally considered a photosynthetic bacterium that plays an important pioneering role in establishing a microflora/fauna community (Wang et al., 2020). Although the stability of bacterial communities significantly affects soil, plant quality, and immunity (Yu et al., 2019), the structure and function of soil microbial communities are influenced by numerous selection factors (Pan et al., 2020). Microbial communities are regarded as a key mechanism affecting soil quality (Bulgarelli et al., 2015). The introduction of agricultural management measures has already been demonstrated to alter the species abundances and composition of the bacterial community after fertilizer application through changes in the $\mathrm{N}$ source (Ramirez et al., 2012). Herein, our results demonstrate that the composition of the bacterial community was significantly affected after straw return under NP and NPK treatments by changing the soil chemical properties (especially in soil, OM, total $\mathrm{N}, \mathrm{NH}_{4}-\mathrm{N}$, $\mathrm{NO}_{3}-\mathrm{N}$ ), indicating that straw return was an important factor that influences soil microbial community for long-term cultivation of rice.
4.3 The effect of straw return on interaction of soil microbes and Si mobility

Soil microbe community and composition play a crucial role in regulating soil properties and processes (Yong and Crawford, 2004; Seaton et al., 2020), which drives the mobility of Si in soils (Cornelis and Delvaux, 2016; Li et al., 2019; Li et al., 2020). However, this effect of soil microbes on soil Si mobility or their interaction is less investigated. According to the results of RDA (Fig. 4) and Spearman correlation analysis (Fig. 5), this study observed that soil microbe community affected or interacted with mobility of $\mathrm{Si}$ in soils by changing the transformation of different Si fractions (Fig. 5). This effect may be attributed to three factors. First, as discussed above, the nutrient input ( $\mathrm{C}$ and $\mathrm{N}$ ) after straw return enhanced the abundance of soil microbes (Table 1; Fig. 2). This enhancement of soil microbes increases the soil residence decomposition, which increases the release of phytolith into soils to improve ASi (BSi) pool. This effect positively corresponds to the relationship that soil Acidobacteria is positively and significantly $(P<0.05)$ related to ASi (Fig. 5B). Acidobacteria is generally considered a predominant bacterial phylum in tropical cropland that improves OM degradation due to its high abundance (Fan et al., 2014; Lee et al., 2008; Kuzyakov and Blagodatskaya, 2015; Kielak et al., 2016). Thus, the espouse of plant phytoliths (BSi) induced by soil microbes via decomposition enhances its dissolution and bioavailable Si release into the soil solution. Second, increased organic carbon after soil residue decomposition may enhance the adsorption of bioavailable $\mathrm{Si}$, resulting in the increase of $\mathrm{Si}$ adsorption in soil organic carbon, which also positively responded to the improvement of soil $\mathrm{OM} \mathrm{Si}$ and $\mathrm{OC}$ concentrations (Table 1; Fig. 1), as well as abundance of soil microbes induced by straw return (Figs. 2 and 3 ). However, Si adsorbed in these OM is converted into mobile or plant-available $\mathrm{Si}$ when soil OM is decomposed by soil microbes, leading to a decrease in OM Si pool. This effect may partly explain why soil Rokubacteria at the phylum level as well as Deltaproteobacteria and Holophagae at the class level was negatively and significantly $(P<0.05)$ related to OM Si (Fig. 5). These findings may suggest that $O C$ input is the most important factor that influences microbial communities after straw return, partly driving $\mathrm{Si}$ mobility by changing the transformation of different Si forms. Third, straw is also rich in $\mathrm{Si}$, except for the input of $\mathrm{C}$ and $\mathrm{N}$. A previous study (Lin et al., 2020) reported that $63.7 \%$ of total bacterial OTUs were regulated by Si source addition regardless of the presence of plants, suggesting that Si source had a direct effect on soil microorganisms. Most interestingly, according to RDA combined with VPA analysis to assess the effects of Si sources on soil bacterial community, Si source was closely related to the soil microbial community (Fig. 4A), since it significantly explained $12 \%$ of the soil bacterial community. This finding suggests that the bacterial community composition may be partly dominated by soil Si pools and that straw return partly 
governs Si mobility by interacting with the bacterial community and abundance, resulting in the decomposition of $\mathrm{OM}$ to enhance the release of phytoliths and their dissolution. This coupling effect leads to soil processes and development that enhance the biological Si cycle to determine agricultural soil sustainability. Specifically, the networks constructed based on both NP and NPK treatment show that bacterial microorganism has more significant influence on yield than chemical and Si fractions (Fig. 6A). However, the networks constructed based on NPS and NPKS treatment reveal that different Si fractions play a larger role in the network and are more related with other microbial nodes (Fig. 6B) that affect rice yields. These findings indicate a significant interaction between soil microbes and Si fractions after straw return under NP or NPK treatment. However, the mechanism by which straw return affects soil microbes and interacts with soluble Si remains unknown. Further studies on Si change alone or with other factors or combinations that drive this mechanism are required.

\section{Conclusion}

Straw return significantly increased available $\mathrm{Si}, \mathrm{OM}$ combined $\mathrm{Si}$, Fe-Mn combined $\mathrm{Si}$, amorphous $\mathrm{Si}$, and rice yield. Long-term straw return significantly enhanced the relative abundance of microbes (Chloroflexi) to accelerate the degradation of straw, but decreased the abundance of Deltaproteobacteria and improved soil health. As a predominant bacterial phylum in tropical cropland that increases OM degradation due to high abundances, soil microbe Actinobacteria enhanced the soil residence decomposition to release plant phytoliths into soils. Thus, the action of plant phytoliths induced by soil microbes enhances Si dissolution and bioavailable Si release into the soil solution. According to the redundancy analysis results, this study further indicate that $\mathrm{Si}$ fractions significantly explained $12 \%$ of the soil bacterial community. These findings suggest that soil microbe community affects or interacts with mobility of $\mathrm{Si}$ in soils by altering the transformation of Si fractions. Therefore, this study indicates that straw return not only supplies and sustains the pool of bioavailable and biogenic Si, but affects the microbial community compositions, which subsequently lead to Si bioavailability, thus balancing the nutrient cycle and improving soil development. This coupling effect induces soil processes and health development, thus enhancing biological Si cycle to determine agricultural soil sustainability.

\section{Conflict of interest}

The authors declare no conflict of interest.

\section{Acknowledgments}

We thank Yunfeng Yang (at Tsinghua University) for constructive input, discussions, and revision of the manuscript. This work was jointly supported by Fundamental Research Funds for Central Non-profit Scientific Institution (Nos. 1610132019011, 1610132020012) and the National Key Research and Development Program of China (Nos.2016YFD0800707, 2016YFD0200109).

\section{References}

Barão, L., Clymans, W., Vandevenne, F., Meire, P., Conley, D.J., Struyf, E., 2014. Pedogenic and biogenic alkaline-extracted silicon distributions along a temperate land-use gradient. European Journal of Soil Science 65, 693-705.

Barberán, A., Bates, S.T., Casamayor, E.O., Fierer, N., 2012. Using network analysis to explore co-occurrence patterns in soil microbial communities. ISME Journal 6, 343-351.

Bei, S., Zhang, Y., Li, T., Christie, P., Li, X., Zhang, J., 2018. Response of the soil microbial community to different fertilizer inputs in a wheat-maize rotation on a calcareous soil. Agriculture, Ecosystems \& Environment 260, 58-69.

Bu, R., Ren, T., Lei, M.J., Liu, B., Li, X.K., Cong, R.H., Zhang, Y.Y., Lu, J.W., 2020. Tillage and straw-returning practices effect on soil dissolved organic matter, aggregate fraction and bacteria community under rice-rice-rapeseed rotation system. Agriculture, Ecosystems \& Environment 287, 106681.

Bulgarelli, D., Garrido-Oter, R., Münch, P.C., Weiman, A., Drröge, J., Pan, Y., McHardy, A.C., Schulze-Lefert, P., 2015. Structure and function of the bacterial root microbiota in wild and domesticated barley. Cell Host \& Microbe 17, 392-403.

Carey, J.C., Fulweiler, R.W., DeGabriel, J., 2015. Human appropriation of biogenic silicon-the increasing role of agriculture. Functional Ecology 30, 1331-1339.

Chen, Y., Xin, L., Liu, J., Yuan, M., Liu, S., Jiang, W., Chen, J., 2017. Changes in bacterial community of soil induced by long-term straw returning. Scientia Agrícola 74, 349-356.

Cooke, J., Leishman, M.R., Hartley, S., 2016. Consistent alleviation of abiotic stress with silicon addition: a meta-analysis. Functional Ecology 30, 1340-1357.

Cornelis, J., Delvaux, B., 2016. Soil processes drive the biological silicon feedback loop. Functional Ecology 30, 1298-1310.

Cornelis, J.T., Delvaux, B., Georg, R.B., Lucas, Y., Ranger, J., Opfergelt, S., 2011. Tracing the origin of dissolved silicon transferred from various soil-plant systems towards rivers: a review. Biogeosciences 8, 89-112.

Coskun, D., Deshmukh, R., Sonah, H., Menzies, J.G., Reynolds, O., Ma, J.F., Kronzucker, H.J., Bélanger, R.R., 2019. The controversies of silicon's role in plant biology. New Phytologist 221, 67-85.

Dobermann, A., Fairhurst, T.H., 2000. Rice: Nutrient Disorders and Nutrient Management, Potash and Phosphate Institute International Rice Research Institute, Singapore Los Banos.

Edgar, R.C., 2010. Search and clustering orders of magnitude faster than BLAST. Bioinformatics (Oxford, England) 26, 2460-2461.

Edgar, R.C., 2013. UPARSE: highly accurate OTU sequences from microbial amplicon reads. Nature Methods 10, 996-998.

Edgar, R.C., Haas, B.J., Clemente, J.C., Quince, C., Knight, R., 2011. UCHIME improves sensitivity and speed of chimera detection. Bioinformatics (Oxford, England) 27, 2194-2200. 
Epstein, E., 1994. The anomaly of silicon in plant biology. Proceedings of the National Academy of Sciences of the United States of America 91, 11-17.

Esperschütz, J., Gattinger, A., Mäder, P., Schloter, M., Fliessbach, A., 2007. Response of soil microbial biomass and community structures to conventional and organic farming systems under identical crop rotations. FEMS Microbiology Ecology 61, 26-37.

Fan, F.L., Yin, C., Tang, Y.J., Li, Z.J., Song, A.L., Wakelin, S.A., Zou, J., Liang, Y.C., 2014. Probing potential microbial coupling of carbon and nitrogen cycling during decomposition of maize residue by ${ }^{13} \mathrm{C}$-DNA-SIP. Soil Biology \& Biochemistry 70, 12-21.

Fraysse, F., Pokrovsky, O.S., Schott, J., Meunier, J.D., 2009. Surface chemistry and reactivity of plant phytoliths in aqueous solutions. Chemical Geology 258, 197-206.

Georgiadis, A., Sauer, D., Herrmann, L., Breuer, J., Zarei, M., Stahr, K., 2013. Development of a method for sequential Si extraction from soils. Geoderma 209-210, 251-261.

Guntzer, F., Keller, C., Poulton, P.R., McGrath, S.P., Meunier, J.D., 2011. Long-term removal of wheat straw decreases soil amorphous silica at Broadbalk, Rothamsted. Plant and Soil 352, 173184.

Guo, L.J., Zhang, Z.S., Wang, D.D., Li, C.F., Cao, C.G., 2015. Effects of short-term conservation management practices on soil organic carbon fractions and microbial community composition under a rice-wheat rotatioin system. Biology and Fertility of Soils 51, 6575.

Hossain, K.A., Horiuchi, T., Miyagawa, S., 2001. Effects of Silicate Materials on Growth and Grain Yield of Rice Plants Grown in Clay Loam and Sandy Loam Soils. Journal of Plant Nutrition 24, 1-13.

Karunakaran, G., Suriyaprabha, R., Manivasakan, P., Yuvakkumar, R., Rajendran, V., Prabu, P., Kannan, N., 2013. Effect of nanosilica and silicon sources on plant growth promoting rhizobacteria, soil nutrients and maize seed germination. IET Nanobiotechnology / IET 7, 70-77.

Keller, C., Guntzer, F., Barboni, D., Labreuche, J., Meunier, J.D., 2012. Impact of agriculture on the Si biogeochemical cycle: Input from phytolith studies. Comptes Rendus Geoscience 344, 739-746.

Kielak, A.M., Barreto, C.C., Kowalchuk, G.A., van Veen, J.A., Kuramae, E.E., 2016. The Ecology of Acidobacteria: Moving beyond Genes and Genomes. Frontiers in Microbiology 7, 744.

Klotzbücher, T., Marxen, A., Vetterlein, D., Schneiker, J., Turke, M., van Sinh, N., Manh, N.H., van Chien, H., Marquez, L., Villareal, S., Bustamante, J.V., Jahn, R., 2015. Plant-available silicon in paddy soils as a key factor for sustainable rice production in Southeast Asia. Basic and Applied Ecology 16, 665-673.

Kurtz, L.D., Derry, L.A., Chadwick, O.A., 2002. Germanium-silicon fractionation in the weathering environment. Geochimica et Cosmochimica Acta 66, 1525-1537.

Kuzyakov, Y., Blagodatskaya, E., 2015. Microbial hotspots and hot moments in soil: Concept \& review. Soil Biology \& Biochemistry 83 , 184-199.

Lee, S.H., Ka, J.O., Cho, J.C., 2008. Members of the phylum Acidobacteria are dominant and metabolically active in rhizosphere soil. FEMS Microbiology Letters 285, 263-269.

Li, J.G., Ren, G.D., Jia, Z.J., Dong, Y.H., 2014. Composition and activity of rhizosphere microbial communities associated with healthy and diseased greenhouse tomatoes. Plant and Soil 380, 337-347.

Li, Z., Cornelis, J.T., Linden, C.V., Van Ranst, E., Delvaux, B., 2020. Neoformed aluminosilicate and phytogenic silica are competitive sinks in the silicon soil-plant cycle. Geoderma 368, 114308.

Li, Z., Delvaux, B., 2019. Phytolith-rich biochar: A potential Si fertilizer in desilicated soils. Global Change Biology. Bioenergy 11, 1264 1282.

Li, Z., Unzué-Belmonte, D., Cornelis, J.T., Linden, C.V., Struyf, E., Ronsse, F., Delvaux, B., 2019. Effects of phytolithic rice-straw biochar, soil buffering capacity and $\mathrm{pH}$ on silicon bioavailability. Plant and Soil 438, 187-203.

Liang, Y., Hua, H., Zhu, Y.G., Zhang, J., Cheng, C., Römheld, V., 2006. Importance of plant species and external silicon concentration to active silicon uptake and transport. New Phytologist 172, 63-72.

Liang, Y., Nikolic, M., Belanger, R., Gong, H., Song, A., 2015. Si in Agriculture. Springer.

Lin, W.P., Jiang, N.H., Peng, L., Fan, X.Y., Gao, X.Y., Wang, G.P., Cai, K.Z., 2020. Silicon impacts on soil microflora under Ralstonia Solanacearum inoculation. Journal of Integrative Agriculture 19, 251-264.

Lu, P., Lin, Y.H., Yang, Z.Q., Xu, Y.P., Tan, F., Jia, X.D., Wang, M., Xu, D.R., Wang, X.Z., 2015. Effects of application of corn straw on soil microbial community structure during the maize growing season. Journal of Basic Microbiology 55, 22-32.

Lugtenberg, B., Kamilova, F., 2009. Plant-growth-promoting rhizobacteria. Annual Review of Microbiology 63, 541-556.

Ma, J.F., Tamai, K., Yamaji, N., Mitani, N., Konishi, S., Katsuhara, M., Ishiguro, M., Murata, Y., Yano, M., 2006. A silicon transporter in rice. Nature 440, 688-691.

Marxen, A., Klotzbucher, T., Kaiser, K., Nguyen, V.S., Schmidt, A., Schadler, M., Vetterlein, D., 2015. Interaction between silicon cycling and straw decomposition in a silicon deficient rice production system. Plant and Soil 398, 153-163.

Marxen, A., Klotzbücher, T., Kaiser, K., Nguyen, V.S., Schmidt, A., Schädler, M., Vetterlein, D., 2016. Interaction between silicon cycling and straw decomposition in a silicon deficient rice production system. Plant and Soil 398, 153-163.

Meunier, J.D., Sandhya, K., Prakash, N.B., Borschneck, D., Dussouillez, P., 2018. pH as a proxy for estimating plant-available Si? A case study in rice fields in Karnataka (South India). Plant and Soil 432, 143-155.

Ning, D., Song, A., Fan, F., Li, Z., Liang, Y., 2014. Effects of slagbased silicon fertilizer on rice growth and brown-spot resistance. PLoS One 9, e102681.

Oksanen, J., Kindt, R., Legendre, P., O'Hara, B., Stevens, M.H.H., Oksanen, M.J., Suggests, M., 2007. The vegan package. Community ecology package, 631-637.

Pan, X., Zhang, S., Zhong, Q., Gong, G., Wang, G., Guo, X., Xu, X., 2020. Effects of soil chemical properties and fractions of $\mathrm{Pb}, \mathrm{Cd}$, and $\mathrm{Zn}$ on bacterial and fungal communities. Science of the Total Environment 715, 136904.

Pereira, S.I., Castro, P.M., 2014. Diversity and characterization of culturable bacterial endophytes from Zea mays and their potential as plant growth-promoting agents in metal-degraded soils. Environmental Science and Pollution Research International 21, 
14110-14123.

Phongpan, S., Mosier, A.R., 2003. Effect of rice straw management on nitrogen balance and residual effect of urea- $\mathrm{N}$ in an annual lowland rice croping sequence. Biology and Fertility of Soils 37, 102-107.

Phutela, U.G., Sahni, N., 2013. Microscopic Structural Changes in Paddy Straw Pretreated with Trichoderma reesei MTCC 164 and Coriolus versicolor MTCC 138. Indian Journal of Microbiology 53 227-231.

Ramirez, K.S., Craine, J.M., Fierer, N., 2012. Consistent effects of nitrogen amendments on soil microbial communities and processes across biomes. Global Change Biology 18, 1918-1927.

Rêgo, M.C.F., Cardoso, A.F., da C Ferreira, T., de Filippi, M.C.C., Batista, T.F.V., Viana, R.G., da Silva, G.B., 2018. The role of rhizobacteria in rice plants: Growth and mitigation of toxicity. Journal of Integrative Agriculture 17, 2636-2647.

Robinson, M.D., McCarthy, D.J., Smyth, G.K., 2010. edgeR: a Bioconductor package for differential expression analysis of digital gene expression data. Bioinformatics (Oxford, England) 26, 139 140.

Sauer, D., Saccone, L., Conley, D.J., Herrmann, L., Sommer, M., 2006. Review of methodologies for extracting plant-available and amorphous $\mathrm{Si}$ from soils and aquatic sediments. Biogeochemistry 80, 89-108.

Samaddar, S., Truu, J., Chatterjee, P., Truu, M., Kim, K., Kim, S., Seshadri, S., Sa, T., 2019. Long-term silicate fertilization increased the abundance of Actionbacterial population in paddy soils. Biology and Fertility of Soils 55, 109-120.

Seaton, F.M., George, P.B.L., Lebron, I., Jones, D.L., Creer, S., Robinson, D.A., 2020. Soil textural heterogeneity impacts bacteria but not fungal diversity. Soil Biology and Biochemistry 144 107766.

Song, A., Li, P., Fan, F., Li, Z., Liang, Y., 2014. The effect of Silicon on photosynthesis and expression of its relevant genes in rice (Oryza sativa L.) under high-zinc stress. PLoS One 9, e113782.

Song, A., Xue, G., Cui, P., Fan, F., Liu, H., Yin, C., Sun, W., Liang, Y., 2016. The role of silicon in enhancing resistance to bacterial blight of hydroponic- and soil-cultured rice. Scientific Reports 6, 24640.

Song, A.L., Fan, F.L., Yin, C., Wen, S.L., Zhang, Y., Fan, X.P., Liang, Y. C., 2017. The effects of silicon fertilizer on denitrification potential and associated genes abundance in paddy soil. Biology and Fertility of Soils $53,627-638$.

Song, A.L., Li, P., Li, Z.J., Fan, F.L., Nikolic, M., Liang, Y.C., 2011. The alleviation of zinc toxicity by silicon is related to zinc transport and antioxidative reactions in rice. Plant and Soil 344, 319-333.

Struyf, E., Smis, A., Van Damme, S., Garnier, J., Govers, G., Van Wesemael, B., Conley, D.J., Batelaan, O., Frot, E., Clymans, W., Vandevenne, F., Lancelot, C., Goos, P., Meire, P., 2010. Historica land use change has lowered terrestrial silica mobilization. Nature Communications 1, 129.

Su, Y., Lv, J.L., Yu, M., Ma, Z.H., Xi, H., Kou, C.L., He, Z.C., Shen, A.L., 2020. Long-term decomposed straw return positively affects the soil microbial community. Journal of Applied Microbiology 128, 138-150.

Team, R.D.C., 2014. R: A Language and Environment for Statistical Computing. R Foundation for Statistical Computing, Vienna, Austria, http://www.R-project.org/ .
Tessier, A., Campbell, P.G.C., Blsson, M., 1979. Sequential extraction procedure for the speciation of particulate trace metals. Analytical Chemistry $51,844-851$.

Vander Linden, C., Delvaux, B., 2019. The weathering stage of tropical siols affects the soil-plant cycle of silicon, but depending on land use. Geoderma 531, 209-220.

Vandevenne, F., Struyf, E., Clymans, W., Meire, P., 2012. Agricultural silica harvest: have humans created a new loop in the global silica cycle? Frontiers in Ecology and the Environment 10, 243-248.

Wang, B., Zheng, X., Zhang, H., Xiao, F., Gu, H., Zhang, K., He, Z., Liu, X., Yan, Q., 2020. Bacterial community responses to tourism development in the Xixi National Wetland Park, China. Science of the Total Environment 720, 137570.

Wang, Q., Garrity, G.M., Tiedje, J.M., Cole, J.R., 2007. Naive Bayesian classifier for rapid assignment of rRNA sequences into the new bacterial taxonomy. Applied and Environmental Microbiology 73, 5261-5267.

Watanabe, F., Olsen, S., 1965. Test of an ascorbic acid method for determining phosphorus in water and $\mathrm{NaHCO}_{3}$ extracts from soil. Soil Science Society of America Journal 29, 677-678.

Wichramasinghe, D.B., Rowell, D.L., 2006. The release of silicon from amorphous silica and rice straw in Sri Lankan soils. Biology and Fertility of Soils 42, 231-240.

Wu, M., Qin, H., Chen, Z., Wu, J., Wei, W., 2011. Effect of long-term fertilization on bacterial composition in rice paddy soil. Biology and Fertility of Soils 47, 397-405.

Xiong, X.Q., Liao, H.D., Ma, J.S., Liu, X.M., Zhang, L.Y., Shi, X.W., Yang, X.L., Lu, X.N., Zhu, Y.H., 2014. Isolation of a rice endophytic bacterium, Pantoea sp. Sd-1, with ligninolytic activity and characterization of its rice straw degradation ability. Letters in Applied Microbiology 58, 123-129.

Yan, C., Yan, S.S., Jia, T.Y., Dong, S.K., Ma, C.M., Gong, Z.P., 2019. Decomposition characteristics of rice straw returned to the soil in northeast China. Nutrient Cycling in Agroecosystems 114, 211224.

Yang, X.M., Song, Z.L., Qin, Z.L., Wu, L.L., Yin, L.C., Zwieten, L.V., Song, A.L., Ran, X.B., Yu, C.X., Wang, H.L., 2020a. Phytolith-rich straw application and groundwater table management over 36 years affect the soil-plant silicon cycle of a paddy field. Plant and Soil 454, 343-358.

Yang, X.M., Song, Z.L., Yu, C.X., Ding, F., 2020b. Quantification of different silicon fractions in broadleaf and conifer forests of northern China and consequent implications for biogeochemical Si cycling. Geoderma 361, 114036

Yong, I.M., Crawford, J.W., 2004. Interactions and self-organization in the soil-microbe complex. Science 304, 1634-1637.

Young, I.M., Crawford, J.W., 2004. Interactions and self-organization in the soil-microbe complex. Science 304, 1634-1637.

Yu, Y., Wu, M., Petropoulos, E., Zhang, J., Nie, J., Liao, Y., Li, Z., Lin, X., Feng, Y., 2019. Responses of paddy soil bacterial community assembly to different long-term fertilizations in southeast China. Science of the Total Environment 656, 625-633.

Zhao, J., Ni, T., Xun, W., Huang, X., Huang, Q., Ran, W., Shen, B., Zhang, R., Shen, Q., 2017. Influence of straw incorporation with and without straw decomposer on soil bacterial community structure and function in a rice-wheat cropping system. Applied 
Microbiology and Biotechnology 101, 4761-4773.

Zhao, Z.B., He, J.Z., Geisen, S., Han, L.L., Wang, J.T., Shen, J.P., Wei, W.X., Fang, Y.T., Li, P.P., Zhang, L.M., 2019. Protist communities are more sensitive to nitrogen fertilization than other microorganisms in diverse agricultural soils. Microbiome 7 , 33. 